\title{
Assembly of Bifunctional Receptors via the Melamine- Barbiturate Structural Motif
}

\author{
Alexander N. Shivanyuk, Dmitry M. Rudkevich, and David N. Reinhoudt* \\ Laboratory of Supramolecular Chemistry and Technology, University of Twente, \\ P. O. Box 217, 7500 AE Enschede, The Netherlands.
}

\begin{abstract}
An assembly of cation receptor 1 and anion receptor 2 via the hydrogen bonding melamine-barbiturate structural motif complexes sodium thiocyanate, sodium iodide, and sodium azide in apolar solvents. Copyright @ 1996 Elsevier Science Ltd
\end{abstract}

The functional noncovalent assemblies of several binding subunits are relevant to biological processes such as oxygen transport and enzymatic catalysis. ' For example, hemoglobin consists of four porphyrincontaining subunits, intercommunicating with each other in the process of oxygen binding. Recently, rationally designed noncovalently assembled energy transfer systems ${ }^{2}$ and receptors ${ }^{3}$ have been reported. We are currently developing a concept of hydrogen bonding assembly of functional receptors. Recently we have described a base-paired self-assembled bifunctional receptor consisting of a calixarene (cation receptor) and a Zn-porphyrin (anion receptor), which strongly complexes NaSCN in toluene. ${ }^{4}$ In this communication we report a self-assembled receptor system based on the melamine-barbiturate binding motif and demonstrate that this self-assembled system binds inorganic sodium salts in apolar solvents. It has been recently established that the melamine-barbiturate motif may result in very stable well-defined cyclic hexamers (rosettes) or linear oligomers depending basically on the geometry and flexibility of the linking fragments. ${ }^{5}$

Our synthetic strategy is based on the functionalization of appropriate receptor moieties with hydrogen bonding sites capable of assembly. Accordingly, the melamine fragment was introduced into the calixarene triester monoamide moiety which selectively binds sodium. ${ }^{6}$ The barbiturate fragment was connected to the Zn-porphyrin which is known as a ligand for anions. ${ }^{7}$ The DCC-HOBT coupling of calixarene monoacid $3^{6}$ with melamine 4 in THF afforded calixarene cation receptor 1. Reaction of porphyrin $5^{8}$ with acid chloride $6^{9}$ in pyridine followed by metallation with $\mathrm{Zn}(\mathrm{OAc})_{2} \cdot 2 \mathrm{H}_{2} \mathrm{O}$ in $\mathrm{CHCl}_{3}-\mathrm{MeOH}(2: 1)$, gave anion receptor 2 . $^{10}$ Cation receptor 1 and anion receptor 2 form the hydrogen bonded aggregate. The ${ }^{1} \mathrm{H}$ NMR titrations of $2\left(10^{-2}\right.$ $\mathrm{M}, \mathrm{CDCl}_{3}, 25^{\circ} \mathrm{C}$ ) with 1 showed characteristic ${ }^{5}$ downfield shifts and broadening of the $\mathrm{NH}$-singlets for both melamine and barbiturate moieties of 1 and 2 , respectively. 
Calixarene 1 effectively complexes $\mathrm{Na}^{+}$, and extraction of sodium perchlorate, thiocyanate, iodide, and azide salts from saturated aqueous solution to $\mathrm{CH}_{2} \mathrm{Cl}_{2}$ gave the corresponding complexes $1 \cdot \mathrm{Na}^{+} \mathrm{X} \cdot\left(\mathrm{X}=\mathrm{ClO}_{4}^{-}\right.$, $\mathrm{I}, \mathrm{SCN}, \mathrm{N}_{3}{ }^{-}$) that are kinetically stable on the NMR time-scale; estimated $K_{\text {ass }}$ values in $\mathrm{CDCl}_{3}$ and $\mathrm{CD}_{3} \mathrm{CN}$ are $>10^{5} \mathrm{M}^{-1}$.

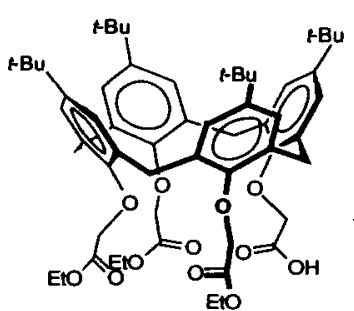

3





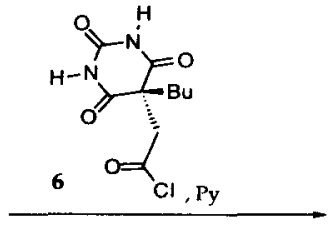

2. $\mathrm{Zn}(\mathrm{OAC})_{2} 2 \mathrm{H}_{2} \mathrm{O}, \mathrm{MeOH}-\mathrm{CHCl}$

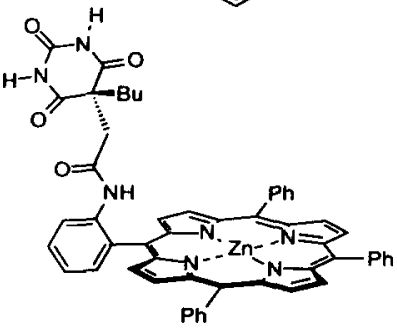

Addition of porphyrin 2 to the solution of $1 \cdot \mathrm{NaX}$ in $\mathrm{CH}_{2} \mathrm{Cl}_{2}$ resulted in strong anion complexation which can be quantitatively characterized by UV-vis spectroscopy. The titrations were performed at $10^{-6} \mathrm{M}$ concentration of 2 and fit very well the model ${ }^{11}$ for $1: 1$ interaction (Table 1); isosbestic points were observed in all cases.

Table 1. Association Constants $\left(K_{\text {ass, }} \mathrm{M}^{-1}\right)$ and Binding Free Energies $\left(\Delta \mathrm{G}^{0}, \mathrm{~kJ} . \mathrm{M}^{-1}\right)$ for Complexation of Porphyrins 2 and 7 with Calixarene Complexes $1 . \mathrm{NaX} .{ }^{a}$

\begin{tabular}{lccccc}
\hline & \multicolumn{2}{c}{2} & & 7 & $\Delta\left(\Delta \mathrm{G}^{0}\right)$ \\
& $K_{\text {ass }}$ & $-\Delta \mathrm{G}^{0}$ & $K_{\text {ass }}$ & $-\Delta \mathrm{G} 0$ & {$\left[\Delta \mathrm{G}^{0}(7)-\Delta \mathrm{G}^{0}(2)\right]$} \\
\hline $1 \cdot \mathrm{NaClO}_{4}$ & $b$ & & $b$ & & \\
$1 \cdot \mathrm{NaSCN}$ & $2.1 \times 10^{3}$ & 18.9 & $9.2 \times 10^{2}$ & 17.0 & 1.9 \\
$1 \cdot \mathrm{NaN}_{3}$ & $5.5 \times 10^{4}$ & 27.0 & $1.5 \times 10^{4}$ & 23.0 & 3.2 \\
$1 \cdot \mathrm{NaI}$ & $5.6 \times 10^{3}$ & 21.3 & $5.0 \times 10^{2}$ & 15.4 & 5.9 \\
\hline
\end{tabular}

a) Measured in $\mathrm{CH}_{2} \mathrm{Cl}_{2}$ at $293 \mathrm{~K},[2]=[7]=1 \times 10^{-6} \mathrm{M} ; b$ ) No binding observed.

As follows from the comparison of $\mathrm{UV}$-vis data, the anion complexation (except $\left.\mathrm{ClO}_{4}\right)$ is strong $\left(-\Delta \mathrm{G}^{0}\right.$ $\left.=15.4-27.0 \mathrm{~kJ} \cdot \mathrm{M}^{-1}\right)$ and there is a preference for azide. Porphyrin 2 possessing a hydrogen bonding site binds 
anions stronger than model porphyrin 7, even at such low concentrations. For instance, the binding constant for the complexation of iodide by porphyrin 2 is 112 times higher than by porphyrin $7\left(\Delta \Delta \mathrm{G}^{0}=5.9 \mathrm{~kJ} . \mathrm{M}^{-1}\right)$. In the presence of $5 \%$ of $\mathrm{MeOH}$, which breaks the hydrogen bonds and strongly solvates the anion, no complexation was observed. These results imply the formation of $(1 \cdot \mathrm{NaX}) \cdot 2$ complex in solution: ${ }^{12}$ the $\mathrm{Na}^{+}$ cation is complexed by calixarene 1 , the anion coordinates to the $\mathrm{Zn}$-porphyrin 2 , and these complexes are assembled through melamine-barbiturate hydrogen bonding. Noteworthy, porphyrins 2 and 7 themselves showed very weak binding with $\mathrm{Bu}_{4} \mathrm{~N}^{+} \mathrm{SCN}^{-}$and $\mathrm{Bu}_{4} \mathrm{~N}^{+} \mathrm{I}^{-}\left(K_{\text {ass }}<10 \mathrm{M}^{-1}\right)$ indicating that in case of calixarene complexes $1 \cdot \mathrm{NaX}$ the ion pair is more separated.
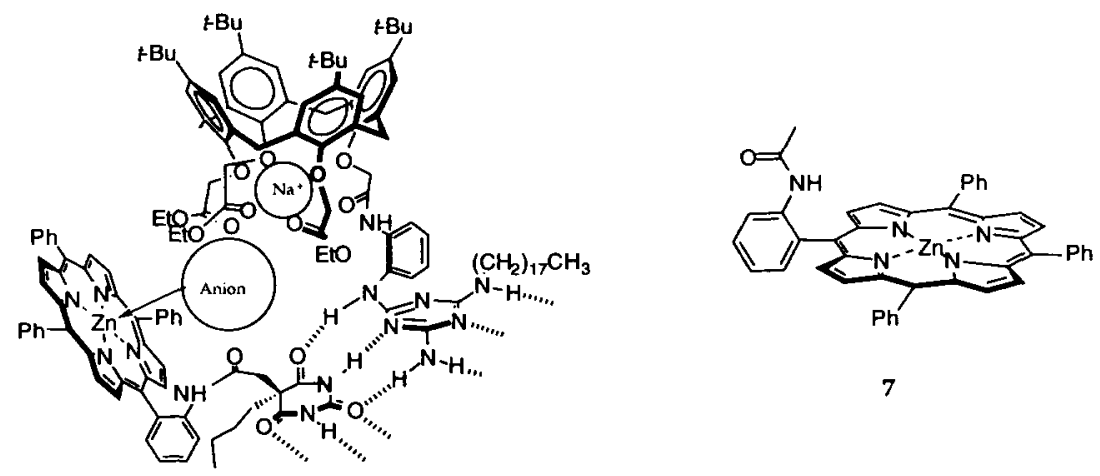

(NaX)e

The strong hydrogen bonding in $(1 \bullet \mathrm{NaX}) \cdot 2$ can be clearly seen by ${ }^{1} \mathrm{H}$ NMR spectroscopy, although at much higher concentration range. Thus, at $10^{-2} \mathrm{M}$ concentration of the components, characteristic ${ }^{5}$ downfield shifts of the NH singlets for both melamine and barbiturate moieties of 1 and 2 were observed, respectively. However, instead rosettes, complex melamine-barbiturate hydrogen-bonded oligomers are formed which makes their quantitative characterization difficult. For example, the ${ }^{1} \mathrm{H}$ NMR spectra of $(1 \cdot \mathrm{NaSCN}) \cdot 2$ and $\left(1 \cdot \mathrm{NaN}_{3}\right) \cdot 2$ are broad but contain clearly the multiplet signal (13.5-14.0 ppm) of the imide protons of the barbiturate moiety. This is in agreement with previously described combinations where the formation of welldefined aggregates (e.g. rosettes) is impossible due to either sterical restrictions or conformational flexibility. ${ }^{5}$ Additionally, electrostatic repulsions between different charges may also prevent the rosette formation. Nevertheless, strong anion binding takes place also in this case; it can be observed by simply following the visible color changes upon addition of $\mathbf{1} \cdot \mathrm{NaX}$ to the solution of porphyrin 2 . In a competition experiment, stepwise addition of $1 \cdot \mathrm{NaSCN}$ to the solution of complex 1.2 disrupted the latter complex and resulted in the formation of $(1 \cdot \mathrm{NaSCN}) \cdot 2$, which can be clearly seen by NMR from appearance of the corresponding signals., In principle, this allows to estimate a relative stability of the aggregate(s) where both cation and anion are bound within assembled bifunctional receptor system. 


\section{REFERENCES AND NOTES}

1. (a) Stryer, L. Biochemistry; $4^{\text {th }}$ ed., W. H. Freeman and Co.; New York, 1995. (b) Lawrence, D. S.; Jiang, T.; Levett, M. Chem. Rev. 1995, 95, 2229. (c) Philp, D.; Stoddart, J. F. Angew. Chem., Int. Ed. Engl. 1996, 35, 1155.

2. Sessler, J. L.; Wang, B.; Harriman, A. J. Am. Chem. Soc. 1995, 117, 85.

3. (a) Branda, N; Wyler, R.; Rebek, Jr., J. Science 1994, 263, 1267. b) Meissner, R. S.; Rebek, Jr, J.; de Mendoza, J. Science 1995, 270, 1485.

4. Rudkevich, D. M.; Shivanyuk, A. N.; Brzozka, Z.; Verboom, W.; Reinhoudt, D. N. Angew.Chem., Int. Ed. Engl. 1995, 34, 2124.

5. (a) Whitesides, G. M.; Simanek, E. K.; Mathias, J. P.; Seto, C. T.; Donovan, N. C.; Mammen, M.; Gordon, D. M. Acc. Chem. Res. 1995, 28, 37. (b) Drain, C. M.; Russel, K. S.; Lehn, J.-M. Chem. Commun. 1996, 337. (c) Vreekamp, R. H.; van Duynhoven, J. P. M.; Hubert, M.; Verboom, W.; Reinhoudt, D. N. Angew. Chem., Int. Ed. Engl. 1996, 35, 1215. (d) Lehn, J.-M. Supramolecular Chemistry: concepts and perspectives; Weinheim: VCH, New York 1995.

The main features of the melamine-barbiturate structural motif, used for the design, are: a) extremely high strength of aggregation, b) the possibility for organization of several particles of two different functions, which allows, in principle, to create an assembly of several functions, c) strong dependence of the stability and stoichiometry on the concentration.

6. Mc Kervey, M. A.; Owens, M.; Schulten, R. H.; Vogt, H; Bohmer, V.; Angew. Chem., Int. Ed. Engl. 1990, $29,280$.

7. Nappa, M.; Valentine, J. S. J. Am. Chem. Soc. 1978, 100, 5075.

8. Collman, J. P.; Brauman, J. I.; Doxsee, K. M.; Helbert, T. R.; Bunnenberg, E.; Linder, R. E.; La Mar, G. N.; Del Gaudio, J. ; Lang, G. ; Spartalian, K. J. Am. Chem. Soc. 1980, 102, 4182.

9. Teccila, P.; Jubian, V.; Hamilton, A. D. Tetrahedron 1995, 51, 435.

10. Selected data for $1: \mathrm{mp} 78-80^{\circ} \mathrm{C}$; MS-FAB $\mathrm{m} / z 1415.8\left(\mathrm{M}^{+}\right.$, calcld 1415.9). Selected data for 2: $\mathrm{mp}$ $>300{ }^{\circ} \mathrm{C}$; UV-vis $\left(\mathrm{CH}_{2} \mathrm{Cl}_{2}\right) \lambda_{\max } 424 \mathrm{~nm}$; MS-FAB m/z $915.2\left(\mathrm{M}^{+}\right.$, calcd 915.3). Satisfactory spectroscopic data and elemental analyses were obtained for all new compounds synthesized. Full experimental details will be published elsewhere.

11. Miller, J. R.; Dorough, G. D. J. Am. Chem. Soc. 1952, 74, 3977.

12. The proposed structures were additionally confirmed by molecular mechanics calculations performed with Quanta/CHARMm Version 3.3. 